18 hours". He lived to see such exposures made as a routine in 1/10 second, even with apparatus that was mobile and could be readily taken round the wards to the patients.

In the rapid evolution of medical radiology and its applications to almost every branch of medicine and surgery, particularly in urinary radiology, Thurstan Holland took a leading part. He was one of the first to demonstrate the presence of a stone in the kidney and to obtain the shadow of the kidney outline as a sine qua non of a satisfactory radiograph of the kidney region. His meticulously careful technique and expert knowledge of photography resulted in the production of radiographs that were far in advance of standard practice for many years. Moreover, he brought to the task of the interpretation of his results exceptional clinical experience that was coupled with logical and rapid judgment. Little wonder, therefore, that he made his mark not only as a pioneer but also as a leader.

Although he practised in Liverpool, he nevertheless found time to keep in close touch with his colleagues in London, where he served on almost every radiological committee of importance. His commanding presence and outstanding personality were asociated with an exceptional rapidity of judgment and a knack of getting down to essentials . His influence on committees was profound.

Thurstan Holland's contributions to the literature of medical radiology were numerous and covered a wide field. So early as 1898-99 he wrote on the successful treatment of lupus and eczema by means of X-rays. Later he turned his attention to the diagnosis of chest conditions and those of the urinary tract. Working with his friend the late Sir Robert Jones, he made many valuable contributions to the study of diseases and abnormalities of bones. The Royal College of Surgeons acknowledged the value of this work by electing him as a fellow of the College. A list of about a hundred of his papers up to 1922 lies before me, covering practically every field of medical radiology that had been explored up to that time.

During the War of 1914-18 Holland served as a Major in the First Western General Hospital. His common-sense methods in the localization of foreign bodies were adopted by many radiologists.

$\mathrm{He}$ attained to all the honours that were possible in his branch of medicine and was president of the Electro-therapeutic Section of the Royal Society of Medicine, of the Roentgen Society (twice), of the British Institute of Radiology, and, highest honour of all, was elected president of the First International Congress of Radiology in 1925.

Outside his profession his hobbies were alpine photography and mountaineering. During the last fifteen years of his life he lived in retirement; but he still took an active interest in radiology and, as doyen of the radiologists, he attended many of the public functions until ill-health supervened. With his passing on January 16 at the age of seventyseven, radiology has lost a leader, the last of the pioneers, who did much to establish this branch of medicine on a sound basis.
A. E. Barclay.

\section{Prof. T. R. Wilkins}

News has been received of the sudden death on December 10 of Prof. Thomas Russell Wilkins, professor of physics in the University of Rochester, New York. He was in his forty-ninth year.

Born in Toronto, Canada, he graduated at MacMaster University and came to Great Britain for post-graduate work at Cambridge. Before going to Rochester he held teaching posts at the University of Chicago, and at Brandon, Canada.

When the Institute of Applied Opties was founded at Rochester in 1928, Wilkins was placed in charge, and the success of the Institute owed a great deal to his interest and enthusiasm. His main scientific interests were always, however, in the realm of atomic physics, and he recently relinquished the optics post in favour of Prof. Brian O'Brien.

Wilkins was an enthusiastic research worker and his main line consisted in the study of cosmic ray and radioactive processes with the aid of photographic emulsions, a technique to which he made notable contributions, but not without long and laborious hours at the microscope.

\section{Prof, K. F. Wenckebach}

Prof. K. F. Wenckebach, an eminent Viennese physician and a founder of modern cardiology, whose death has recently been announced, was born at The Hague on March 24, 1864. After serving as an assistant at the Institute of Zoology and Pathology of Utrecht, he was appointed professor of internal medicine at Groningen in 1901, where he remained until 1911, when he was transferred to the corresponding chair at Strassburg. He held this post until 1914, when he was appointed professor of medicine at Vienna, retiring in 1929. He at first devoted his attention to embryology, but his subsequent work, for which he is best known, was concerned with the pathology and clinical aspects of cardiovascular disease and particularly cardiac arrhythmia. In 1920, in association with Prof. Jagic, he founded the Wiener Archiv für innere Medizin, of which his students offered him a Festschrift on the occasion of his retirement in 1929. During the occupation of his chair at Vienna he attracted a large number of practitioners and students interested in cardiology. He had many friends in Great Britain, where he was elected an honorary fellow of the Royal College of Physicians in 1928 and of the Royal Society of Medicine in 1930. J. D. Rolleston.

WE regret to announce the following deaths :

Sir Frederick Banting, K.B.E., F.R.S., professor of medical research in the University of Toronto, on February 21, aged forty-nine.

Prof. William J. A. Bliss, emeritus professor of physics in the Johns Hopkins University, on Decem. ber 27, aged seventy-three.

Dr. J. G. Priestley, reader and demonstrator in clinical physiology in the University of Oxford, on February 9. 